\title{
WHY DO CONSUMERS MAKE ONLINE SHOPPING? THE EFFECT OF BIG FIVE PERSONALITY TRAITS, NARCISSISM AND SELF-ESTEEM
}

\author{
*Alev Kocak Alan \\ *Ebru Tumer Kabadayı \\ **Sema Gunduz \\ *Gebze Technical University, Turkey
}

\begin{abstract}
This research aims to investigate consumers' personality effect in online shopping intention to deepen our understanding and extending empirical evidence. A conceptual framework was designed with Narcissism, Self-esteem and Big-five personality traits. This model was examined by using a field questionnaire with the structural equation modelling; the data were collected from 420 online shoppers. Findings revealed that narcissism, self-esteem and big five personality traits are important drivers of costumers online shopping intention. These results may assist e-retailers to increase their number of visitors if online shoppers will be provided with more accurate online store elements (web page design, transactions, products or services etc.) according to different types of personalities.
\end{abstract}

Keywords: Narcissism, Self-esteem, Big Five, Personality traits, Online shopping intention

JEL Classification: M31, M39, L29

\section{INTRODUCTION}

Today, the Internet offers many venues for the improvement of people's lives and therefore there are many reasons given for the increased growth and development of Internet usage since the internet is founded. Humanity is assisted with Internet in terms of quick communication, easily reaching to a great amount of information, easy accessibility and its ease of use for everybody, (Bonn et al.,1999). The development of Internet provides online shopping alternative to conventional brick and mortar store for companies in the $21^{\text {st }}$ century (Gupta and Sharma, 2003: 46). Therefore, physical stores are not the only channel for shopping, online stores are the productive option for shoppers with the variety of products offers, deep information about products, convenient shopping environment, and privacy during product choosing, so that online shopping became popular among consumers and today it is actively in use (Levy and Weitz, 2009).

Several authors focus on online shopping in a variety of fields. Early studies are mainly interested in online shopping attitude and behaviour (Bhatnagar et al., 2000; Lee et al.,2001; Borchers, 2001; Kim and Lim, 2001). Bhatnagar et al. (2000) research the impacts of product or service features, online store design and consumers' demographics on online shopping attitude and thus online purchasing behaviour. There are also many studies in consumer trust and risk-taking issue in an online shopping perspective. The process of online shopping includes the consumers perception of financial, time, opportunity and performance risk (Lee et al., 2001). More importantly, studies reveal that people care a lot about their security and privacy during their online shopping (Bhatnagar et al., 2000; Borchers, 2001). Consumer satisfaction is the other research subject in online shopping (Heiner et al., 2004). Kim and Lim (2001) proof an interaction between information quality and online shopping satisfaction. Szymanski and Hise (2000) find that web page design had the important influence on consumer satisfaction towards the online shop. Researchers have also investigated consumers' characteristics and their online shopping attitude; Ing-Wu (2003) reportes that the significant consumer characteristics influence customers' online shopping attitude and customers' product choosing decisions. This kind of studies may prove the influence of potential customer characteristics on online shopping, however understanding prospective 
online shoppers' personality traits and its effects on their shopping intention seemed an underdeveloped area for researchers.

Pertinently, researchers that are more recent have tended to report relationships between personality traits and online shopping behaviour of customers (Karl et al., 2007a; Chen and Lee, 2008; Dobre and MilovanCiuta, 2015). Bosnjak et al. (2007) indicates that the personality traits and online buying behaviour relationship has been weakly studied and identified the personality determinants of online shopping behaviour. Karl et al. (2007a) find that people from different personality types use online shopping for their different aspects. Dobre and Milovan-Ciuta (2015) investigat the association between personality traits and online shopping and they reports that consumer personality variable is internal value and it has a significant influence on the online shopping behaviours. Additionally, Chen and Lee (2008) find supporting result from their empirical research and it is mentionedthat the personality traits leverages hedonic, utilitarian values of online shopping pages.

The goal of this research is to improve the knowledge about big five, self-esteem and narcissism personality traits and their substantial effects on online shopping intention. Building on previous research on personality traits and online shopping intention, we investigate how consumers' narcissism and selfesteem affect theironline shopping differ depending on their personality in a holistic view. According to our knowledge, previous studies mainly focus on the effect of personality traits on social media usage of the individuals (Ryan and Xenos, 2011; Wang et al., 2012). Our study addresses the gap in the literature by studying the effect of the big five personality traits, self-esteem and narcissism on online shopping intention.

\section{LITERATURE REVIEW}

Cultural, social and personal, and psychological characteristics have an intense power on consumers buying decision, which are difficult for monitoring over by marketing professionals, however, marketers must care about the issue (Armstrong and Kotler, 2000). Those characteristics are divided into external factors and internal factors.External factors refer as demographic, social, economic and technologic, while the internal factors can be listed as personal beliefs, attitudes, motives and values.

There is no doubt that individual's decision-making in any issue dependent on his/her personality traits (Lauriola and Levin, 2001). Likewise, Im et al. (2003) report that the demographic and psychological characteristics affect consumers' tendency to innovations. Citrin et al.(2000) expressthat because of different personal characteristics, innovation adoption differs among consumers.

Online shopping is a distribution channel for sellers where consumers buy product or service on the internet on their own without any intermediary services. Online shopping atmosphere provides consumers with various online stores, different products options, online payment transaction and delivering items to their doors. Therefore, people intend to shop online as they can save time, they can also find an extensive variety of products and buy the product that is suitable for their budget.

Online shopping intention indicates consumers' willingness to buy a product from online stores and it is usually measured by consumers' motivation to purchase products online and to purchase from online stores again ( $\mathrm{Li}$ and Zhang, 2002). It was also founded that individuals' self-efficacy and normative behaviour associated with their online shopping intention (Vijayasarathy, 2004).

Consumers' online shopping intention is influenced by several variables such as attitude towards online shopping, perceived usefulness, ease of use, past shopping experience and perceived risk (Rizwan et al., 2014). which are mentioned at technology acceptance model (Davis, 1985) Pachauri (2002) investigates the reasons of online shopping behaviour and grouped them into four approaches;, namely, economics of information,, cognitive costs,, lifestyle, and contextual influence. Consumers are able to shop by exploring offers from merchants' web page under economic reasons. Cognitive cost approach let consumers make decisions about trust, product quality of sellers. Lifestyle approach means consumers expectation from the online shops such as social interaction and sufficient product information. Contextual influence approach is about accepting a recommendation from others. Additionally, Donthu and Garcia (1999) find the significant result that personality traits are determinants of online shopping behaviour. Only some studies already discovered that consumers' intention to shop online is related to 
personal characteristics. Bosnjak et al. (2007) mention that agreeableness, Openness and Neuroticism, three different personality traits are antecedents

of online shopping behaviour, but this study is limited in the research design in terms of participants' online shopping experience because during the time this study implemented online shopping is in slightly practice in Croatia. Karl et al. (2007a) find that people with different personality use online shopping for the different aspects. Specifically, extraversion, neuroticism, and openness are aligning with customers' hedonic benefits; those people are seeking entertaining, attraction etc. when they do shopping. With the respect to the past studies, the conceptual model is developed and represented in Figure 1.

\section{RESEARCH MODEL AND HYPOTHESES}

Figure 1. Conceptual Framework

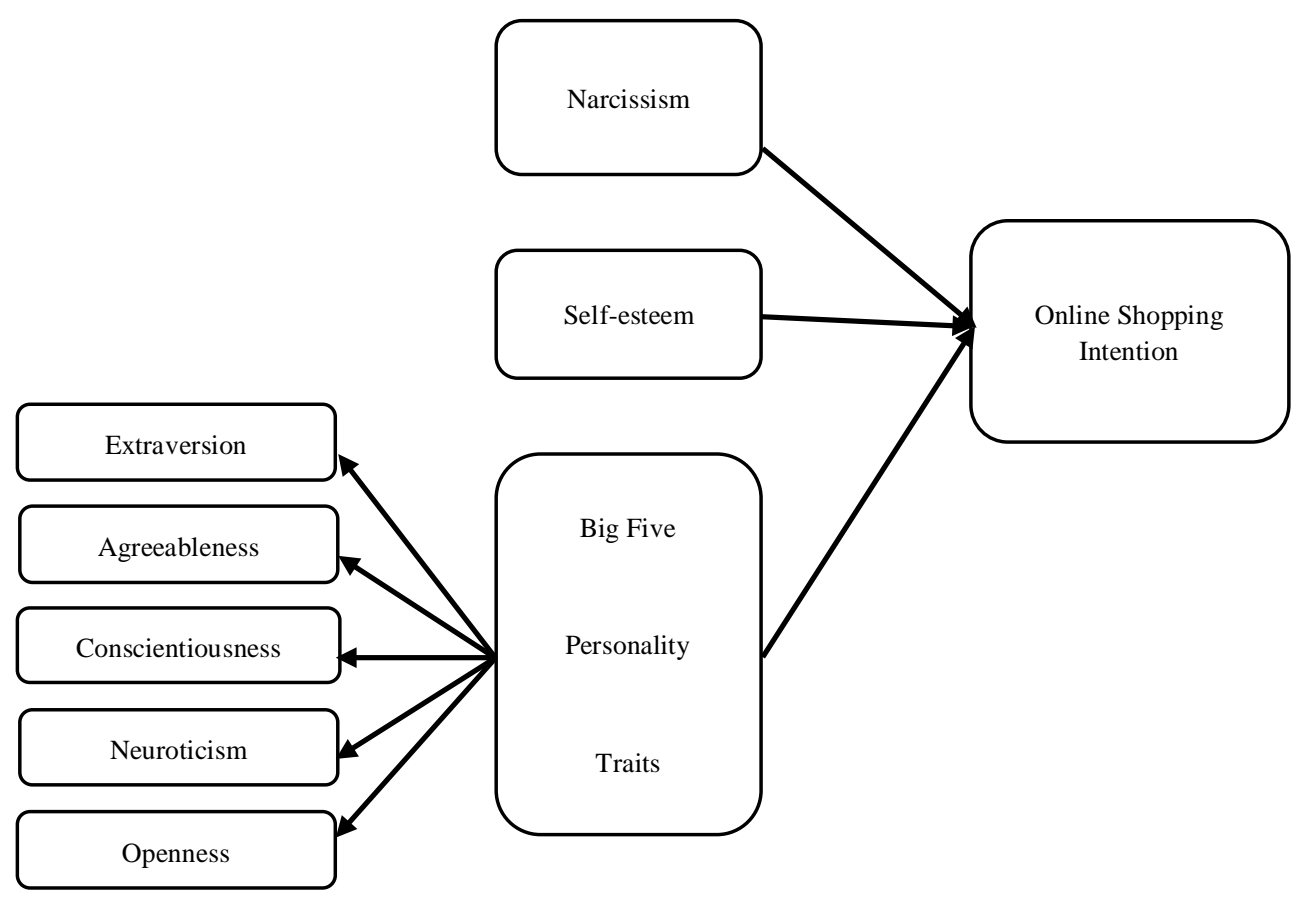

\section{Narcissism and Online Shopping Intention}

Narcissism was principally become a construct with Freud's psychoanalytic explanations (Raskin and Terry, 1988). Freud's theory explained the narcissism attitude based on sexuality and self-love. Deep down, individuals' original libido directing its energy to an object or the ego that cause narcissistic behaviour such as megalomania, egoism, lack of empathy (Krizan and Herlache, 2017). Narcissists are defined as self-centred, egocentric, dominant, self-aggrandizing and manipulative people (Emmons, 1987). Narcissist people think that they are special, they have high-class status and they endeavour to exhibit their overvalued self-appearance to others (Cai et al.2015). The Narcissistic Personality Inventory (NPI) consists of seven dimensions, classically assesses narcissism: authority, entitlement, exhibitionism, exploitation, self-sufficiency, superiority, and vanity (Raskin and Hall, 1979). Narcissists score high on them (Raskin and Terry, 1988). It can be predicted that narcissists engage in conspicuous shopping for their self-image and they need to purchase hedonic value providing products, therefore they are sustaining their self-aggrandizing with expensive and different consumer goods (Sedikides et al.2007). Morf and Rhodewalt (2001) indicate that narcissists highly needed to be noticed by their peers and it is unsurprising that they generally search for latest and greatest products currently on sale, which is easy and productive today to find products via the Internet (Sedikides et al., 2007).

Under above discussion, narcissism can be also related with materialism due to narcissists tendency to show-off their precious belongings. For instance, they are presenting their luxury and unique goods and 
thus they are an opinion leader, dominant and charismatic among their peers (Lambert and Desmond, 2013). According to early literature, the underlying mechanism of purchasing products and services is not only getting benefit for their utility needs but also having self-image exhibition (Levy, 1959; Leighand Gabel, 1992). Kates' (2002) research also implicates people’ need for an exhibit and participants confess about their intention to show that they have money. As a result, individual, who are prone to narcissism, buy products very often because of his or her looking in a good health requirements (Naderi and Paswan, 2016). Naderi and Paswan (2016) particularly investigate that narcissists’ high-quality product purchase intention from high-end or low-end stores has no difference and consumers purchase products from both store types, furthermore they find that narcissists love shopping from high-end stores which provides them with their luxury brand shopping bag and they can give a clue to others that they can buy from this expensive store.

Today, narcissism is in the centre of researchers on new media users, consumer culture, celebrity culture which became a popular topic in the beginning of the $21^{\text {st }}$ century when myself millennium is started (Tyler, 2007). Digital narcissists are more prone to using digital channels for self-existence and yearn attention from people by their shopping intention in every type of shopping channel (Park et al., 2014).In brief, we predict that narcissist do shopping especially for their charm and they should utilize every shopping channel for their desired product purchasing. Therefore;

H1: The personality of narcissism is positively related to online shopping intention.s-isp:

\section{Self-Esteem and Online Shopping Intention}

Self-esteem means the evaluation of a person's own value to him/herself and it can be a positive or negative attitude which reveals someone's worth, importance, success, and abilities (Peer, 1982; Weiten, 2004). Cast and Burke (2002) suggest that self-esteem is involved with the self-verification of identities in social environments. If individual' identity is confirmed by social groups, it causes an increase in selfesteem score, moreover self-verification is achieved. Moreover, self-esteem is not the only measurement of individuals' socialization level, it is also an anxiety defending system and the close relationship also an important component of self-esteem which is the natural security system (Kiper and Sosis, 2016). It can stop the horrible antisocial behaviour in terms of terrorism (Pyszczynski et al., 2004). Previous studies have shown that self-esteem and information technology usage have a relationship, especially people in low self-esteem who direct to the online communication tools because they think that face to face communication is concerning activity (Joinson, 2004; Phillips et al., 2006). Ehrenberg et al. (2008) also contribute this relationship and people, who have low self-esteem, addictively use the instant messaging tool on their mobile phones. Ellison et al. (2007) investigate that Facebook's social benefits to individuals with a variety of self-esteem levels and find that people with low self-esteem can get positive social opportunities on this platform. Wang et al. (2012) find a positive relationship between self-esteem and social networking sites usage, individuals with self-esteem utilize there for commenting their friend pages, because they feel that their opinions are valuable to others and they also follow social media pages of companies as their shopping platform which allows them to choose the product, pay for it and share their comments about the product with others and they can socialize at the same time. Another research revealed that individuals with self-esteem participate Facebook for sharing their ideal selves (Gonzales and Hancock, 2011).

Researchers also investigate the relationship between self-esteem and consumer behaviour (Rucker et al.2012; Wang, et al., 2014; Khare and Sadachar, 2014; Ye et al., 2015). Wang et al. (2014) indicate that people with high self-esteem are positive, affirmative and they do not care others opinion, therefore they consume whatever they like, on the opposite side people, who have low self-esteem, form a negative opinion about their view and they care others opinion, thus their consumption is affected by others evaluations. Rucker et al. (2012) find that people who have low self-esteem also have a tendency to consume luxury products because of their desire to get a high status, which contributes their image. Ye et al.(2015) research the moderating role of self-esteem on a luxury brand connection of consumers, their findings prove that low self-esteem sense causes people to consume expensive products for their statue, it is opposite for consumers with high self-esteem level. Khare and Sadachar (2014) study the effect of collective self-esteem on consumer' online shopping attitude with a comparison of American and Indian university students. They find that both young consumers are affected by group identity. Participant in 
both countries gives importance to group members behaviour while gravitating towards online shopping websites. Because of high technology usage of people with self-esteem sense and group identity affection on them, it is predicted that the online shopping intention will be great for people with high self-esteem personality. The following hypothesis derived from above discussion:

H2: The personality of self-esteem is positively related to online shopping intention.s[i-p:

\section{Big Five Personality Traits and Online Shopping Intention}

Over the last twenty years, researches on personality agree in a general aspect which accepts the big-five personality traits a measurement of the most outstanding phenomenon of personality (Goldberg, 1990). The big five personality trait is entitled to the most useful classification in personality traits (Barrick et al., 2001). Costa and McCrae (1992) mention the big five model as the most extensive and economic model to understand personality differences. The big five model is a demonstration of a broad categorization of individual personality traits and identifies five major personality components as neuroticism, extraversion, agreeableness, openness to experience, and conscientiousness (Costa and McCrae, 1990). Furthermore, it is an instrument for individuals who can measure themselves by rating five bipolar factors' specific aspects (McCrae and John, 1992; Gosling et al., 2003). Devaraj et al. (2008) suggest that the big five personality trait foresees internet related issues better than cognitive approach. AmichaiHamburger (2002) indicate that personality is the major predictor of online behaviour.

Extraversion is positive emotional, social, energetic and expressive statement (McCrae and John, 1992). Tsao and Chang (2010) indicate that extroversive persons strongly value their external image and willingly adopt changes through new things and ideas. Saleem et al. (2011) report that people with extraversion personality desire social recognition, status, and power. Even they are more likely to take on leadership roles. Socialization is also quite a high level for extroverts; they interact with others in terms of sharing their experiences and accepting to consider the suggestions of others (Matzler et al.2006). According to empirical findings, extraversion is positively related to adaptation of new applications. Extroverts enjoy using information technologies (Saleem et al., 2011). Khare and Singh (2010) investigate the effect of personality types on customer's evaluation about online banking in India and they found that extroverts tend to take a risk to utilize innovation, thus they use online banking. Other researchers look at differences in personality traits on online shopping behaviour and they found out that extroversive consumers expect enjoyment, fun, socialization opportunities and store aesthetics during their online shopping (Tsao and Chang, 2010; Dobre and Milovan-Ciuta, 2015). Wang et al. (2012) also find that extraverted people use social media mainly widen their social networks. Despite the prediction that extraverts would engage in more online shopping when it is fun and social, neither Tsao and Chang (2010) nor Dobre and Milovan-Ciuta (2015) do not mention any significant relationship between extraversion personality and online shopping intention. Online shopping environment can be designed for different personality types in B2C companies (Tsao and Chang, 2010).

Agreeableness is proposed by Digman and Inouye (1986) as agreeableness people are most likely to build a friendly relationship with others. That means, people who have high degree of agreeableness, give importance to the people around them and their characteristics gathered around the dimensions of altruism, modest, kindness, personable (Costa, McCrae and Dye, 1991; McCrae and John, 1992). Karl et al. (2007a) indicate that consumers with higher agreeableness are influenced by visual effects on online shopping pages and they are glad to interact with other consumers there. Moreover, Violet et al. (2004) identify a relationship between agreeable people and tendency to engaging beneficial activities. During their online shopping, they search for alternatives to find the best utilitarian offer. Similarly, Chen and Lee (2008) express that online shopping pages would be convenient in revealing beneficial values for a consumer is higher in agreeableness. Finally, agreeable people are more tend to make utilitarian shopping (Tsao and Chang, 2010). Previous studies report a positive relationship between agreeableness and utilitarian value (Violet, 2004; Chen and Lee, 2008) but past researches do not indicate clear relationship between agreeableness and online shopping intention.

Conscientious people are generally individualist, self-controlled, detail oriented, neat and well organized, they are responsible, hardworking and they always pursue their goals (Costa et al., 1991; McCrae and John, 1992). Previous studies find that conscientious online shoppers recognize and accumulate 
information and choose the best product among alternatives, which fit their social statue (Karl et al., 2007a). However, Tsao and Chang's (2010) empirical findings do not show any hedonic or utilitarian motivation of conscientiousness towards shopping. Saleem et al. (2011) investigate conscientious people and their computer usage and they find the positive relationship between them. Especially, conscientious women strongly use a computer in their daily life and they are potential customers for online shopping environment. It is expected that merciful people attach in online shopping due to their highly organized and detail oriented way of life.

Neuroticism consists of characteristics such as nervous, hostile, depressive, self-conscious, isolated, vulnerable and impulsive (Costa and McCrae, 1992). Barrick and Mount (1991) explained neuroticism as emotional stability and this personality type can be seen in every personality measures (Judge et al.1999). Karl et al.(2007b) discovered in their study that people low in neuroticism tended to be more relaxed, peaceful, joyful, and they seek for more fun. However, Saleem et al. (2011) find a negative relationship between neuroticism and computer use, nevertheless, Tsao and Chang (2010) indicate that consumers with the higher degree of neuroticism who experience negative emotions are actively engage in online shopping. Because they want to overcome their emotional pain and they feel relieved and happy when they receive their parcels by post. Furthermore, neurotics find online shopping productive and functional in terms of comparing products from different sellers in best price, purchasing an item at the lowest price and meeting their expectation easily (Tsao and Chang, 2010). If individuals are more neurotic, it will be hard for them to control their emotions and stop buying a whim. Neurotics also give importance attract the others' attention, because they wish to be compared with their peers and so they may tend to spend more for some products to be different than their peers (Zywica, and Danowski, 2008). Consequently, Tsao and Chang (2010) find that neurotics have hedonic and utilitarian buying motivation towards online shopping activity.

Openness represents traits associated with curiosity, open-mindedness, and originality (Barrick and Mount, 1991; Costa and McCrae, 1992). Individuals who have high level of openness are seeking to learn new things, they are open to new experiences and therefore they have positive attitudes toward new technology. Saleem et al. (2011) point out that they use computer actively. It is, therefore possible that individuals with open to experience, are willing to find new and best offers on internet shopping. Matzler et al. (2006) find that consumers with the high degree of openness to experience can be caught by emotional stimuli during their online searching and shopping. Chen and Lee (2008) investigate how a customer with openness influenced by hedonic shopping value and especially website visual content design. They found that openness moderates the influence of website contents on hedonic shopping value. If website provide good quality pictures of the product and broad range of alternatives, price information and so on, a customer with openness will tend to shop there. On the other hand, Tsao and Chang (2010) find out the more open people, the more tendency for utilitarian and hedonic shopping motivation. Eventually, people with openness character shop online for both utilitarian and hedonic benefits.

Frequently, big five personality traits is used to measure technology usage intention, social media participation and shopping behaviour (Guido, 2006; Ryan and Xenos, 2011; Saleem et al., 2011; Wang et al., 2012). The big five personality traits have recently been researched in the variety of online shopping related issues. Picazo-Vela et al. (2010) investigated the personality of online reviewers in online stores; neuroticism and conscientiousness drive people to make reviews. Barnett et al. (2015) test the effect of the big five on actual technology use in the classroom and it is found that extraversion, conscientiousness, and neuroticism is related with people' tendency to use technology. Anaza (2014) mention that agreeable and extrovert customers' satisfaction and citizenship to the online store is high due to their empathic concerns. According to Mendonca (2016) three of the five personality traits (extraversion, openness to experience and conscientiousness) is related to online buying behaviour. Consumers with a higher degree of big five tend to shop online;

H3. The big five personality traits is positively related to online shopping intention. 


\section{RESEARCH METHODOLOGY}

\section{Sample/Data}

In order to figure out the relationship between personality traits and online shopping intention, a survey was utilized. The populations in this study were internet users in Turkey. To collect the data, an online survey distributed among social media and e-mailing groups. Participants told that they would be assessing their personality and online shopping intention. Earlier in data collection, the questionnaire was pretested through a pilot test by 26 participants. Questionnaire items were revised according to the feedbacks from the pilot test before its final form.

The survey was included in 35 items which were separated into four parts. The data was collected in the period from April 2017 to July 2017. This study used the convenience sampling technique to obtain convenient participants. Consequently, 420 surveys were collected from the period of April to July 2017, four months of data collection. Table 1 represents the demographic characteristics of the sample

Table 1. Demographic characteristics of sample $(n=420)$

\begin{tabular}{llrr}
\hline Characteristics & N & \% \\
\hline Gender & & & \\
& Male & 173 & 41.2 \\
& Female & 247 & 58.8 \\
Age & & & \\
& $<20$ & 56 & 13.3 \\
& $20-30$ & 261 & 62.1 \\
& $31-40$ & 75 & 18 \\
& $41-50$ & 22 & 5.2 \\
& $>51$ & 6 & 1.4 \\
Education level & & \\
& High school & 39 & 9.3 \\
University & 314 & 74.7 \\
Graduate school & 67 & 16 \\
\hline
\end{tabular}

\section{Measures}

In this study, the survey includes four parts. The first part comprised of questions to measure demographic characteristics of the sample.The following parts are prepared to measure participants' personality traits and online shopping intention.

For all scales in this study, the five-point Likert-type scale was utilized to measure each construct). Narcissism personality trait variable was measured by using 3 items (special, aware of what to do and a good person) were adopted from the study of Taylor and Strutton (2016). The next variable is self-esteem personality measured by using six items (having good qualities, a person of worth and reversed items adapted not good at all, useless, wishing to respect myself, a failure) from Rosenberg (1965). The online shopping intention scale was drawn from online shopping attitude and intention scale of Vijayasarathy (2004). Finally, for the last variable big five personality traitsmeasurement items were taken from John et al. (1991).. Measurement items were displayed in Table 2. 
Table 2. Measurement items

\begin{tabular}{|c|c|c|c|c|c|}
\hline Construct & & $\begin{array}{l}\text { Standardized } \\
\text { loadings }\end{array}$ & $\begin{array}{l}\text { Cronbach's } \\
\text { Alpha }\end{array}$ & CR & AVE \\
\hline $\begin{array}{l}\text { Narcissism } \\
\text { Special } \\
\text { Aware of what to do } \\
\text { A good person }\end{array}$ & & $\begin{array}{l}0.55^{* *} \\
0.72^{* *} \\
0.53^{* *}\end{array}$ & 0.628 & 0.631 & 0.367 \\
\hline $\begin{array}{l}\text { Self esteem } \\
\text { Not good at all (R) } \\
\text { Have good qualities } \\
\text { Useless (R) } \\
\text { A person of worth } \\
\text { Wishing to respect myself (R) } \\
\text { A failure (R) }\end{array}$ & & $\begin{array}{l}0.64^{* *} \\
0.62^{* *} \\
0.64^{* *} \\
0.72^{* *} \\
0.77^{* *} \\
0.60^{* *}\end{array}$ & 0.824 & 0.827 & 0.446 \\
\hline Big Five Personality Traits & & & 0.684 & 0.773 & 0.415 \\
\hline $\begin{array}{l}\text { Extraversion } \\
\text { Enthusiastic } \\
\text { Energetic } \\
\text { Reserved (R) }\end{array}$ & $\begin{array}{l}0.74^{* *} \\
0.88^{* *} \\
0.82^{* *}\end{array}$ & $0.68^{* *}$ & 0.854 & 0.856 & 0.665 \\
\hline $\begin{array}{l}\text { Agreeableness } \\
\text { Person who find others' faults (R) } \\
\text { Helpful } \\
\text { Warm } \\
\text { Kind } \\
\text { Rude (R) } \\
\text { Cooperative }\end{array}$ & $\begin{array}{l}0.65^{* *} \\
0.77^{* *} \\
0.76^{* *} \\
0.84^{* *} \\
0.59^{* *} \\
0.62^{* *}\end{array}$ & $0.75^{* *}$ & 0.851 & 0.858 & 0.505 \\
\hline $\begin{array}{l}\text { Conscientiousness } \\
\text { Careless (R) } \\
\text { Lazy (R) } \\
\text { Persevering } \\
\text { Efficient }\end{array}$ & $\begin{array}{l}0.63^{* *} \\
0.67^{* *} \\
0.80^{* *} \\
0.69^{* *}\end{array}$ & $0.76^{* *}$ & 0.783 & 0.793 & 0.490 \\
\hline $\begin{array}{l}\text { Neuroticism } \\
\text { Calm } \\
\text { Tense (R) }\end{array}$ & $\begin{array}{l}0.73 \\
0.80\end{array}$ & $0.46^{* *}$ & 0.720 & 0.739 & 0.586 \\
\hline $\begin{array}{l}\text { Openness } \\
\text { Imaginative } \\
\text { Inventive }\end{array}$ & $\begin{array}{l}0.77^{* *} \\
0.89^{* *}\end{array}$ & $0.51^{* *}$ & 0.809 & 0.818 & 0.693 \\
\hline $\begin{array}{l}\text { Online Shopping Intention } \\
\text { I like using the Internet for shopping. } \\
\text { I use the Internet frequently to do my shopping. } \\
\text { I use the Internet whenever appropriate to do my shopping. } \\
\text { I probably will use the Internet in the near future for } \\
\text { shopping. }\end{array}$ & & $\begin{array}{l}0.79^{* *} \\
0.90^{* *} \\
0.71^{* *} \\
0.93^{* *}\end{array}$ & 0.887 & 0.903 & 0.701 \\
\hline
\end{tabular}

Note: R denotes reverse-scored items; CR denotes composite construct reliability and AVE denotes average variance extracted.

\section{Measure Assessment}

Confirmatory factor analysis (CFA) was implemented with using the maximum likelihood estimation technique to measure validity and reliability on the multiple-items which are personality traits Narcissism, Self-esteem, the big fiveand online shopping intention. Table 2 also displays factor loadings and reliability estimates for each construct. For assessing the reliability and validity of measures Cronbach's alpha coefficient, composite reliability scores and average variance extracted were calculated. Composite reliability (CR) results varied between 0.60 and 0.90 and Cronbach's alpha estimates ranged from 0.62 to 0.90 which are in acceptable limit (Hair et al., 1998; Tseng et al., 2006) For each relevant construct, every individual items' factor loadings were shown in Table 2. which were all large and significant except some, all factor loadings were above 0.5 which suggested the convergent validity of factors. According to Fornel and Larcker (1981), discriminant validity can be evaluated by comparing the shared variance between pairs of latent factors which is calculated for each measure in the measurement model with average variance extracted (AVE). Discriminant validity of measurement was tested by comparing AVE estimates with squared correlations between the constructs. For all constructs AVE estimates are greater 
Journal of Global Strategic Management | V. 11 | N. 2 | 2017-December | isma.info | 005-020 | DOI: 10.20460/JGSM.2018.249

than the estimated squared correlations of construct, therefore discriminant validity was proved (Fornell and Larcker 1981).

More importantly, there was an acceptable fit between measurement model and the observed data: $\chi^{2}$ : 960,44; df: 423; $\chi^{2} / \mathrm{df}=2.27$, Goodness-of-fit index $(\mathrm{GFI})=0.87$, Incremental-fit-index (IFI) $=0.91$, Comparative-fit-index (CFI) $=0.91$. Furthermore, Root Mean Square Error of Approximation (RMSEA) indicated a good fit with 0.05 (Hair et al., 1998: 642).

\section{Hypothesis Testing}

Following the evaluation of the measurement model, structural model of the hypothesis was examined using the maximum likelihood method in AMOS 16. Inter-correlations among eight constructs used in the study are presented in Table 3 with the means and standard deviations (SD).

Table 3. Descriptive statistics and correlation matrix

\begin{tabular}{lccllll}
\hline & Mean & SD & $\mathbf{1}$ & $\mathbf{2}$ & $\mathbf{3}$ & $\mathbf{4}$ \\
\hline 1. Big Five Personality Traits & 3.779 & .504 & 1 & & & \\
2. Narcissism & 3.893 & .569 & $.459^{* *}$ & 1 & & \\
3. Self Esteem & 3.989 & .553 & $.553^{* *}$ &, $635^{* *}$ & 1 & \\
4. Online shopping intention & 3.345 & .992 & .071 &, $182^{* *}$ &, $167^{* *}$ & 1 \\
\hline
\end{tabular}

Note: Correlation is significant at ${ }^{* *} \mathrm{p}<0.01 ;{ }^{*} \mathrm{p}<0.05$

The result from the analysis revealed that goodness of fit statistics was in the acceptable levels $\left(\chi^{2}\right.$ : 992.56; df: $395 ; \chi^{2}$ /df: 2.51; GFI $=0.87$, IFI $=0.89$; CFI $=0.89$; RMSEA $=0.06$ ) which supported the overall fit of proposed model to our data. Figure 2 shows the structural equation model with the estimated path coefficients for the hypothesized constructs.

Figure 2. Structural equation model with parameter estimates

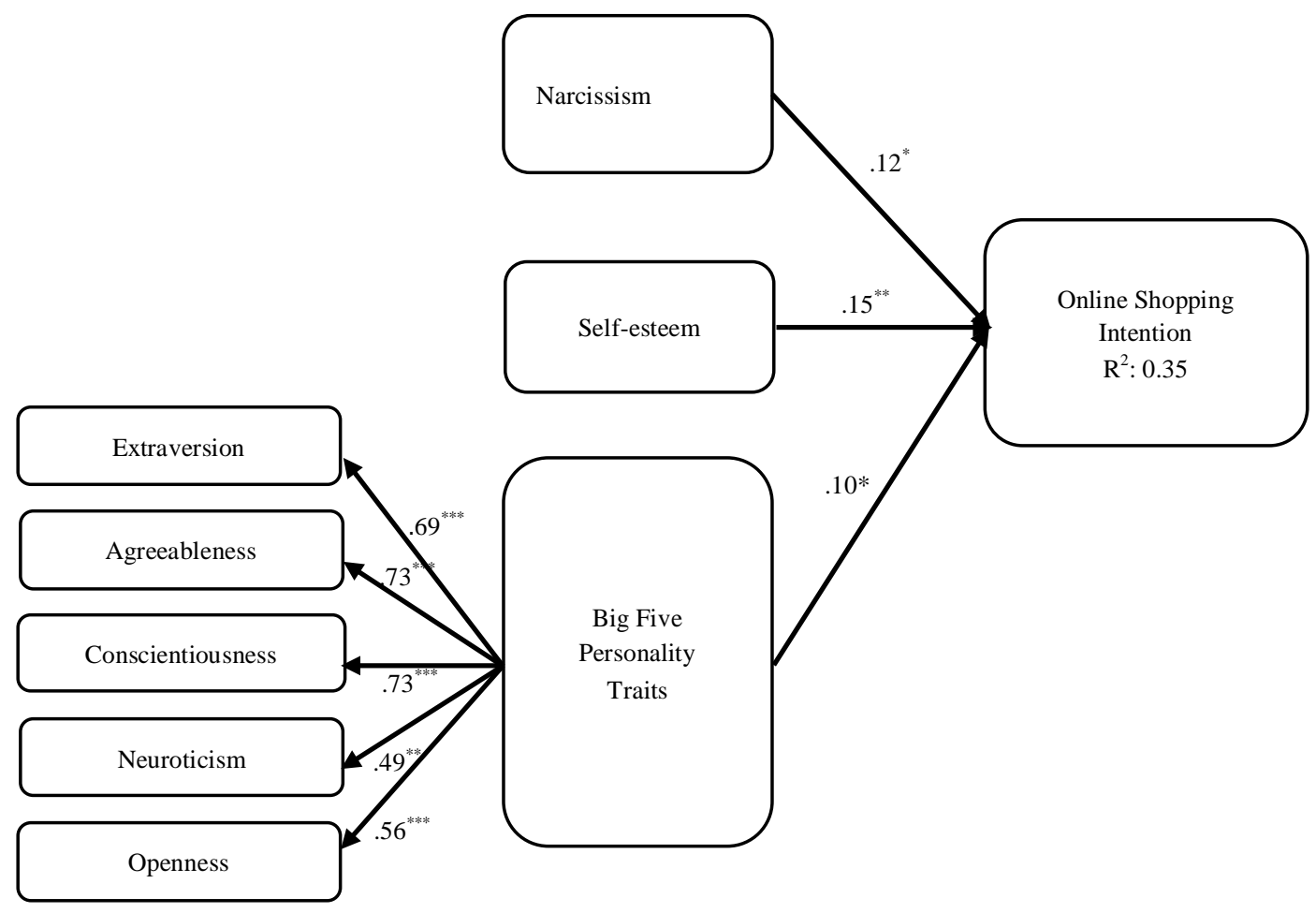

Note: Parameter estimates ${ }^{* * *} \mathrm{p}<0.001 ;{ }^{* *} \mathrm{p}<0.01 ;{ }^{*} \mathrm{p}<0.05$

The analysis shows that three hypotheses were accepted. Online shopping intention was found to be significantly affected by narcissism personality trait $(.03, \mathrm{p}<0.1)$ and $\mathrm{H} 1$ was supported. Self-esteem personality trait was found to be a significant factor of online shopping intention $(.03, \mathrm{p}<0.05)$ and $\mathrm{H} 2$ 
was supported. Big five personality traits also were found to be significantly effective on online shopping intention $(.1, \mathrm{p}<0.1)$. and $\mathrm{H} 3$ was supported.

It is important to note that conceptual framework of this study posited big five personality traits as a single variable. Thus, the current analysis suggested a second order analyse in the model for big five personality traits. When hypothesis concerning personality hierarchical organization of multiple facets are studied, the second order disaggregation model is acceptable (Bagozzi and Heatherton, 1994). In this study, H3 tested as a single variable to test the big five personality traits in total. Therefore, in representing the results in Table 4, $\mathrm{H3}$ is given as a single hypothesis.

Table 4. Structural parameter estimates

\begin{tabular}{lccccc}
\hline Hypothesized paths & Estimate & S.E. & C.R. & p- value & Results \\
\hline H1: Narcissism $\rightarrow$ online shopping intention & 0.12 & 0.03 & 1.80 & $0.07^{*}$ & Supported \\
H2: Self-esteem $\rightarrow$ online shopping intention & 0.15 & 0.03 & 2.86 & $0.01^{* *}$ & Supported \\
H3: Big five $\rightarrow$ online shopping intention & 0.10 & 0.1 & 1.69 & $0.09^{*}$ & Supported \\
${ }^{* *} \mathrm{p}<0.01 ;{ }^{*} \mathrm{p}<0.05$ & & & & &
\end{tabular}

\section{CONCLUSIONS AND RECOMMENDATION}

This study investigates narcissism, self-esteem and thebig five personality traits effects on consumers' online shopping intention to provide awareness about personality differences and their expectation on which marketer should prepare their online selling pages regarding the personality issue to bring more customers to their online stores. The results revealed that narcissism, self-esteem and big five personalities have a considerable effect on individuals' online shopping intention $\left(\mathrm{R}^{2}\right.$ : \%35). These results are similar with Bosnjak et al. (2017) in which it is suggested that consumer personality has an influence on online purchasing behaviour. It can be assumed that narcissist give importance to luxury products and high-class store design, while individuals high on openness tend to give importance to new technology, product alternatives, and virtual design. That means personality variable influence customers' online shop visit and purchase decision. In the online shopping context, marketers should develop their online context with taking into consideration of this personality drivers. As an example, at the final stage of the shopping they can make a personality test to their customer and if the customer is more intent to narcissism, the company can follow him/ her by social network and announce his/her shopping. By this way; narcissist customer may yearn attention by other people and feel special from it.

Personality variable can be also utilized as a segmentation tool in which marketers design their strategies according to different personality groups. In today's competitive market customization is also high in use and marketing professionals need to know very well their customer's personality.

However, personality is not the only variable to influence customers' online shopping intention. There are other factors drive or not to drive people to online shop that can be counted as safety, risk-taking, traditional store visiting preference, fitting rooms' requirement etc.

Furthermore, the correlation between personality traits and online purchasing intention differs from country to country which means that there should be other factors affecting customers' personality and their online shopping preferences in different regions. Further research can be conducted into other driving factors, which influence the personality characteristics, and therefore online shopping intention in different countries. It is suggested that a cross-cultural study might be useful for international brands to understand the different correlation between personality and online shopping intention.

Additionally, it is obvious that social media and online advertising methods are vital to bringing more customers to shop in certain brands and it would be beneficial to expose the influence of social media and online advertising on the different personalities' online shopping intention.

Future research needs to be extended to multi channels in the same context; as an example; offline channels. It would give chance to compare the strength and weakness of each channel. By this means, it would be a great guidance for personality traits importance on online and offline shopping and give 
Journal of Global Strategic Management | V. 11 | N. 2 | 2017-December | isma.info | 005-020 | DOI: 10.20460/JGSM.2018.249

chance to marketers to react in the different type of the shopping channels. Moreover, it is suggested that the big five personality would be examine separately in future studies within the different contexts. Also, further studies may focus on the role different types of personalities.

On the other hand, research has some limitations. The main limitation of the study is the average age of the sample. The big amount of the sample is between 20-30 years old. Because of their generation, this population might have more intention to online shopping. 


\section{REFERENCES}

Amichai-Hamburger, Y., (2002), Internet and personality. Computers in Human Behavior, 18, pp.1-10.

Anaza, N. A., (2014), Personality antecedents of customer citizenship behaviors in online shopping situations. Psychology \& Marketing, 31(4), pp.251-263.

Armstrong, G., \& Kotler, P., (2000), Marketing (5th ed.) Englewood Cliffs, New Jersey: Prentice-Hall.

Bagozzi, R. P., \& Heatherton, T. F., (1994), A general approach to representing multifaceted personality constructs: Application to state self-esteem. Structural Equation Modeling: A Multidisciplinary Journal, 1(1), pp.35-67.

Barnett, T., Pearson, A. W., Pearson, R., \& Kellermanns, F. W., (2015), Five-factor model personality traits as predictors of perceived and actual usage of technology. European Journal of Information Systems, 24(4), pp.374-390.

Barrick, R. M., \& Mount, M. K., (1991), The Big Five personality dimensions and job performance: A meta-analysis. Personnel Psychology, 44, pp. 1-26.

Barrick, R. M., Mount, M. K., \& Judge, T., (2001), Personality and performance at the beginning of the new millennium: What do we know and where do we go next? International Journal of Selection and Assessment, 9(1\&2), pp.9-30.

Bhatnagar, A, Misra, S., \& Rao, H. R., (2000), Online risk, convenience, and Internet shopping behaviour. Communications of the ACM, 43(11), pp.98-105.

Bonn, M. A., Furr, H. L., \& Susskind, A. M., (1999), Predicting a Behavioral Profile for Pleasure Travelers on the Basis of Internet Segmentation. Journal of Travel Research, 37(4), pp.333-340.

Borchers, A., (2001), Trust in Internet shopping: A test of a measurement instrument. Proceedings of the 7th Americas Conference on Information Systems, pp.799-803.

Bosnjak, M., Galesic, M., \& Tuten, T., (2007), Personality determinants of online shopping: Explaining online purchase intentions using a hierarchical approach. Journal of Business Research, 60, pp.597-605.

Cai, H., Shi, Y., Fang, X., \& Luo Y.L.L., (2015), Narcissism predicts impulsive buying: phenotypic and genetic evidence. Frontiers in Psychology, 6(881), pp.1-11.

Cast, A. D., \& Burke, P. J., (2002), A theory of self-esteem. Social forces, 80(3), pp.1041-1068.

Chen, S., \& Lee, K., (2008), The role of personality traits and perceived values in persuasion: an elaboration likelihood model perspective on online shopping. Social Behavior and Personality, 36(10), pp. 1379-1400.

Citrin, A. V., Sprott, D. E., Silverman , S. N., \& Stem, D. E., (2000), Adoption of internet shopping: The role of consumer innovativeness . Industrial Management \& Data Systems, 100(7), pp.294-300.

Costa, P. T., \& Mc Crae, R. R., (1990), Personality disorders and the five-factor model of personality. Journal of Personality Disorders, 4, pp.362-371.

Costa, P. T., McCrae, R. R., \& Dye, D. A., (1991), Facet scales for Agreeableness and Conscientiousness: A revision of the NEO Personality Inventory. Personality and Individual Differences, 12, pp.887-898.

Costa, P., Jr., \& McCrae, R., (1992), NEO personality inventory-revised (NEO-PI-R) and NEO fivefactor inventory (NEO-FFI) professional manual. Odessa, FL: Psychological Assessment Resources.

Davis, F. D. (1985). A technology acceptance model for empirically testing new end-user information systems: Theory and results (Doctoral dissertation, Massachusetts Institute of Technology).

Devaraj, S., Easley, R. F., \& Crant, J. M., (2008), Research note - How does personality matter? Relating the five-factor model to technology acceptance and use. Information Systems Research, 19(1), pp.93-105.

Digman, J. M., \& Inouye, J., (1986), Further specification of the five robust factors of personality. Journal of Personality and Social Psychology, 50, pp.116-123. 
Dobre, C., \& Milovan-Ciuta, A., (2015), Personality influences on online stores customers behaviour. Ecoforum, 4(1), pp.69-76.

Donthu, N., \& Garcia, A., (1999), The Internet shopper. Journal of Advertising Research, 39(3), pp.5258.

Ehrenberg, A., Juckes, S., White, K. M., \& Walsh, S. P., (2008), Personality and self- esteem as predictors of young people’s technology use. Cyberpsychology and Behavior, 11, pp.739-741.

Ellison, N. B., Steinfield, C., \& Lampe, C., (2007), The benefits of Facebook “friends”': Social capital and college students' use of online social network sites. Journal of Computer-Mediated Communication, 12(4), pp.1143-1168.

Emmons, R. A., (1987), Narcisism: Theory and measurement. Journal of Personality and Social Psychology, 52, pp.11-17.

Freud, S., (1914), 'On narcissism; an introduction'. The standard edition of the complete psychological works of Sigmund Freud, 14, pp.73-102.

Fornell, C., \& Larcker, D. F., (1981), Evaluating Structural Equation Models with Unobservable Variables and Measurement Error. Journal of Marketing Research, 18(1), pp.39-50.

Goldberg, L., (1990), An alternative 'description of personality': The big five factor structure. Journal of Applied Psychology, 59, pp.1216-1229.

Gonzales, A. L., \& Hancock, J. T., (2011), Mirror, mirror on my Facebook wall: Effects of exposure to Facebook on self-Esteem. Cyberpsychology, Behavior, and Social Networking, 14(1-2), pp.79-83.

Gosling, S. D., Rentfrow, P. J., \& Swann, W. B., (2003), A very brief measure of the Big-Five personality domains. Journal of Research in personality, 37(6), pp.504-528.

Guido, G., (2006), Shopping motives, big five factors, and the hedonic/utilitarian shopping value: an integration and factorial study. Innovative Marketing, 2(2), pp.57-67.

Gupta, J. N. D., \& Sharma, S. K., (2003), Intelligent Enterprises of the 21th century. Hershey, PA: Idea Group Publishing.

Hair, J.F., Anderson, R.E., Tatham, R.L., \& Black W. C., (1998), Multivariate Data Analysis (5th ed.) Upper Saddle River, New Jersey: Prentice-Hall.

Heiner, E., Gopalkrishnan, R. I., Josef, H., \& Dieter, A., (2004), E-satisfaction: a re-examination. Journal of Retailing, 80(3), pp.239-247.

Im, S., Bayus, B. L., \& Mason, C., (2003), An empirical study of innate consumer innovativeness, personal characteristics, and new-product adoption behaviour. Journal of the Academy of Marketing Science, 31(1), pp.61-73.

$\mathrm{Wu}, \mathrm{S}$. I., (2003), The relationship between consumer characteristics and attitude toward online shopping. Marketing Intelligence \& Planning, 21(1), pp.37-44.

John, O. P., Donahue, E. M., \& Kentle, R. L., (1991), The Big Five Inventory (Versions 4a and 54.) Berkeley, CA: University of California, Berkeley, Institute of Personality and Social Research.

Joinson, A. N., (2004), Self-esteem, interpersonal risk, and preference for e-mail to face-to-face communication. Cyberpsychology \& Behavior, 7, pp.472-478.

Judge, T. A., Higgins, C. A., Thoresen, C. J., \& Barrick, M. R., (1999), The big five personality traits general mental ability, and career success across the life span. Personnel Psychology, 52(3), pp.621-652.

Karl, K. A., Peluchette, J. V., \& Hall, L., (2007a), Give them something to smile about: A marketingoriented approach to volunteer recruitment and retention. Proceedings of the Annual Meeting of the Association of Collegiate Marketing Educators (pp.222-254). South Charleston, WV: Association of Collegiate Marketing Educators. 
Karl, K. A., Peluchette, J. V., \& Harland, L., (2007b), Is fun for everyone? Personality differences in healthcare providers' attitudes toward fun. Journal of Health and Human Services Administration, 29(4), pp.409-447.

Kates, S. M., (2002), The protean quality of subcultural consumption: An ethnographic account of gay consumers. Journal of Consumer Research, 29, pp.383-399.

Khare, A., \& Sadachar, A., (2014), Collective Self-Esteem and Online Shopping Attitudes among College Students: Comparison between the U.S. and India. Journal of International Consumer Marketing, 26(2), pp.106-121.

Khare, A., Khare, A., \& Singh, S., (2010), Role of consumer personality in determining preference for online banking in India. Journal of Database Marketing \& Customer Strategy Management, 17, pp.174187.

Kim, S. Y., \& Lim, Y. J., (2001), Consumers' perceived importance of and satisfaction with internet shopping. Electronic Markets, 11(3), pp.148-54.

Kiper, J., \& Sosis, R., (2016), Why terrorism terrifies us. Evolutionary Psychology and Terrorism, pp.103-123.

Krizan, Z., \& Herlache, A. D., (2017), The narcissism spectrum model: A synthetic view of narcissistic personality. Personality and Social Psychology Review, 1088868316685018.

Lambert, A., \& Desmond, J., (2013), Loyal Now, but Not Forever! A Study of Narcissism and Male Consumer-Brand Relationships. Psychology and Marketing, 30(8), pp.690-706.

Lauriola, M., \& Levin, I. P., (2001), Personality traits and risky decision-making in a controlled experimental task: An exploratory study. Personality and Individual Differences, 31(2), pp.215-226.

Lee, D., Park, J., \& Ahn, J., (2001), On the explanation of factors affecting e-commerce adoption, Proceedings of the 22nd International Conference on Information Systems, pp.109-120.

Leigh, J. H., \& Gabel, T. G., (1992), Symbolic interactionism: its effects on consumer behaviour and implications for marketing strategy. Journal of Services Marketing, 6(3), pp.5-16.

Levy, S. J., (1959), Symbols for sale. Harvard Business Review, 37, pp.117-124.

Levy, M., \& Weitz, B., (2009), Retailing Management (7th ed.) New York: McGraw-Hill Irwin.

Li, N., \& Zhang, P., (2002), Consumer online shopping attitudes and behavior: An assessment of research. AMCIS 2002 Proceedings, 74, pp.508-517.

Matzler, K., Bidmon, S., \& Kräuter, S. G., (2006), Individual determinants of brand affect: the role of the personality traits of extraversion and openness to experience. Journal of Product \& Brand Management, 15 (7), pp.427-434.

Mendonca, M. R., (2016), Relating Big Five Factor Model to the Acceptance and Use of On-line Shopping. International Journal of Marketing Studies, 8(3), pp.89-98.

McCrae R. R., \& John, O. P., (1992), An introduction to the five-factor model and its applications. Journal of Personality, 60(2), pp.175-215.

Morf, C. C., \& Rhodewalt, F., (2001), Unraveling the paradoxes of narcissism: a dynamic self-regulatory processing model. Psychological Inquiry, 12(4), pp.177-196.

Naderi, I., \& Paswan, A. K., (2016), Narcissistic consumers in retail settings. Journal of Consumer Marketing, 33(5), pp.376-386.

Pachauri M., (2002), Researching online consumer behaviour: current positions and future perspectives. Journal of Customer Behaviour, 1(2), pp.269-300.

Park, M. S., Shin, J. K., \& Ju, Y., (2014), Social networking atmosphere and online retailing. Journal of Global Scholars of Marketing Science, 24(1), pp.89-107. 
Peer, G. G., (1982), The Antecedents of Self-Esteem (One of Education's Best Kept Secrets). The Journal of Humanistic Education and Development, 21, pp.18-21.

Phillips, J., Butt, S., \& Blaszczynski, A., (2006), Personality and self-reported use of mobile phones for games. Cyberpsychology \& Behavior, 9(6), pp.753-758.

Picazo-Vela, S., Chou, S. Y., Melcher, A. J., \& Pearson, J. M., (2010), Why provide an online review? An extended theory of planned behavior and the role of Big-Five personality traits. Computers in Human Behavior, 26(4), pp.685-696.

Pyszczynski, T., Greenberg, J., Solomon, S., Arndt, J., \& Schimel, S., (2004), Why do people need selfesteem? A theoretical and empirical review. Psychological bulletin, 130(3), pp.435-468.

Raskin, R. N., \& Hall, C. S., (1979), A narcissistic personality inventory. Psychological reports.

Raskin, R., \& Terry, H., (1988), A principal-components analysis of the Narcissistic Personality Inventory and further evidence of its construct validity. Journal of personality and social psychology, 54(5), pp.890-902.

Rizwan, M., Umair, S. M., Bilal, H. M., Akhtar, M., \& Bhatti, M. S., (2014), Determinants of customer intentions for online shopping: A Study from Pakistan. Journal of Sociological Research, 5(1), pp.248272.

Rosenberg, M., (1965), Society and the adolescent self-image. Princeton, NJ: Princeton University Press.

Rucker, D. D., Galinsky, A. D., \& Dubois, D., (2012), Power and Consumer Behavior: How Power Shapes Who and What Consumers Value. Journal of Consumer Psychology, 22, pp.352-368.

Ryan, T., \& Xenos, S., (2011), Who uses Facebook? An investigation into the relationship between the Big Five, shyness, narcissism, loneliness, and Facebook usage. Computers in Human Behavior, 27, pp.1658-1664.

Saleem, H., Beaudry, A., \& Croteau, A.M., (2011), Antecedents of computer self-efficacy: a study of the role of personality and gender. Computers in Human Behavior, 27(5), pp.1922-1936.

Sedikides, C., Gregg, A. P., Cisek, S., \& Hart, C. M., (2007), The I that buys: narcissists as consumers. Journal of Consumer Psychology, 17(4), pp.254-257.

Szymanski, D.M., \& Hise, R.T., (2000), E-satisfaction: an initial examination. Journal of Retailing, 76(3), pp.309-22.

Taylor, D. G., \& Strutton, D., (2016), Does Facebook usage lead to conspicuous consumption? The role of envy, narcissism and self-promotion. Journal of Research in Interactive Marketing, 10(3), pp.231-248.

Tsao, W.C., \& Chang, H.R., (2010), Exploring the impact of personality traits on online shopping behaviour. African Journal of Business Management, 4(9), pp.1800-1812.

Tseng, W., Dornyei, Z., \& Schmitt, N., (2006), A New Approach to Assessing Strategic Learning: The Case of Self-Regulation in Vocabulary Acquisition. Applied Linguistics, 27(1), pp.78-102.

Tyler, I.., (2007), From 'the me decade' to 'the me millennium' The cultural history of narcissism. International Journal of Cultural Studies, 10(3), pp.343-363.

Vijayasarathy, L. R., (2004), Predicting consumer intentions to use on-line shopping: the case for an augmented technology acceptance model. Information and Management, 41, pp.747-762.

Violet, T. H., Weingart L. R., \& Denise, M. R., (2004), Responses to broken promises: Does personality matter. Journal of Vocational Behavior, 65(2), pp.276-293.

Wang, J., Jackson, L. A., Zhang, D., \& Su, Z., (2012), The relationships among the Big Five Personality factors, self-esteem, narcissism, and sensation-seeking to Chinese University students' uses of social networking sites (SNSs). Computers in Human Behavior, 28, pp.2313-2319. 
Journal of Global Strategic Management | V. 11 | N. 2 | 2017-December | isma.info | 005-020 | DOI: 10.20460/JGSM.2018.249

Wang, X., Cai, W., Sun, J.Q., Wu, S., Feng, Z.Q., \& Jin, S.H., (2014), The Development and Comparison of Power: From the Perspective of Social Psychology Theory. Advances in Psychological Science, 22, pp.139-149.

Weiten, W., (2004), Psychology themes and variations. Belmont, CA: Wadsworth/ Thomson Learning.

Ye, S.-H., Liu, X.-T., \& Shi, S.-Y., (2015), The Research of Status’s Influence on Consumers’ Self-Brand Connection with Luxury Brands: Moderating Role of Self-Esteem and Vanity. Open Journal of Business and Management, 3, pp.11-19.

Zywica, J., \& Danowski, J., (2008), The faces of Facebookers: Investigating social enhancement and social compensation hypotheses; predicting Facebook ${ }^{\mathrm{TM}}$ and offline popularity from sociability and selfesteem, and mapping the meanings of popularity with semantic networks. Journal of Computer-Mediated Communication, 14(1), pp.1-34. 